\title{
BGN Gene
}

National Cancer Institute

\section{Source}

National Cancer Institute. BGN Gene. NCI Thesaurus. Code C105838.

This gene plays a role in extracellular matrix structure. 